\title{
Feedback Study on Developing Critical Literacy among Malawian and Zambian Undergraduate University Students Using a Freirean Praxis
}

\author{
Matthews Tiwaone Mkandawire ${ }^{1}$, Gabriel Walubita ${ }^{2}$ \\ ${ }^{1}$ Curriculum and Philosophy, Education and Communication Department, Lilongwe University of Agriculture and \\ Natural Resources, P.O. Box 219, Lilongwe, Malawi \\ ${ }^{2}$ Educational Psychology, Sociology and Special Education Department, School of Education, University of Zambia, \\ P.O.Box 32379, Lusaka, Zambia
}

Correspondence: Matthews Tiwaone Mkandawire, Curriculum and Philosophy, Education and Communication Department, Lilongwe University of Agriculture and Natural Resources, P.O. Box 219, Lilongwe, Malawi

Received: October 27, 2014

doi:10.11114/jets.v3i2.680

\author{
Accepted: November 3, 2014 Online Published: February 13, 2015
}

URL: http://dx.doi.org/10.11114/jets.v3i2.680

\begin{abstract}
Educators in Malawi and Zambia have always been concerned with their student's abilities to become analytical, logical and proficient readers of texts. This has been due to the fear that there is an increased overemphasis on knowledge of the fundamental literacy skills and other basics at the expense of critical thinking. This scenario has resulted into increased criticism of the quality of the educational product in the above countries. Different studies hence have indicated that most students graduate from university in possession of varying amounts of knowledge but without understanding the purpose of that knowledge in the real world. The students' low proficiency in critical literacy skills presents various social, cultural and educational challenges. This is also shown through improper demonstration of these skills in the work place and the social world. Hence, the goal of this study was to investigate the level of critical literacy among university students. The study used the constructivism theory, as in the Paulo Freire's typology and the qualitative design to collect data through in-depth interviews among students from Lilongwe University of Agriculture and Natural Resources and from University of Zambia. Twenty students were randomly sampled from both universities constituting 40, but only 37 respondents were finally involved due to attrition. The results revealed that most of the responses provided by the students fell in the descriptive or functional phase, the most basic level of critical literacy. These results suggest that universities should do more to promote the higher level of literacy (here after critical literacy) which would make students more rigorous, analytical and better change agents of their worlds and the worlds of others.
\end{abstract}

Keywords: critical literacy, liberative pedagogy, freirean praxis

\section{Introduction}

\subsection{Preamble}

This paper presents an analytical assessment of Paulo Freire's meaning of critical literacy with reference to higher education. First, the paper uses literature review to frame different categories of literacy education in the Frerean Praxis. Second, the paper presents research findings on how undergraduate students understand their learning and what they think is good and bad learning. By way of discussion, the paper classifies students' responses into Freire's levels of literacy based on data from the in-depth interviews and focus group discussions made from the two universities.

\subsection{Background Information}

Research shows that students' abilities to take a critical approach when reading texts is an important aspect of literacy instruction (Stevens, 2007). This is because interpreting texts through a critical literacy lens can help students become aware of the messages that texts communicate about power, race, and gender; who should receive privileges; and who has been or continues to be oppressed. As students learn how to engage in critical literacy, they also become more aware of their views and how their views influence their interpretations of texts and interactions with people. Students can begin to take greater control over how they position themselves and each other while transforming their everyday lives (Lobron \& Selman, 2007). 
Educators in Malawi and Zambia have always been concerned with their students' abilities to master effective reading and writing skills. There is also an increased emphasis on knowledge of the basic reading and thinking processes and not complex literacy in both countries. Many have argued that this situation has greatly been propounded by 'massification' which resulted from introduction of Free Primary Education (FPE); and in some cases by inadequate capacity by governments and academicians to handle academic challenges of managing the balance between quality and quantity needed (Gumport et al., 1997 \& Brandenburg and Zhu, 2007). No wonder, there has been increased criticism of the quality of the educational product in both countries that many students graduate from the university without expected logical and other higher level thinking skills (RUFORUM, 2010). The students' low proficiencies in critical literacy skills present various social, cultural and educational challenges. The purpose of this study was to investigate the level of critical literacy among university students in Malawi and Zambia. This was done by critically defining literacy in a Freirean typology and examining the definitions against Cummins' (1980) critical literacy theoretical framework. The paper further suggests how Freire's critical pedagogy (liberating education ${ }^{1}$ ) could be employed by lecturers in Malawian and Zambian Universities.

\section{Theoretical Understanding of the Study}

In their attempts to confront the evils of social injustice and inequalities, social critical theorists developed the concept of "critical literacy". One of the most outstanding education critical theorists, Paulo Freire (1921-1997), argued that human beings have an ontological vocation to be fully human because they are 'beings of praxis' where praxis is 'a dialogical unity of reflection and action' (McLaren and Learnald, 1993:96). Praxis is therefore a situation where minds meet to honestly discuss issues (not people) and reflect on them in order to change the world. Although humans have this ability, unequal power relationships are still prevalent in society. Through institutions like schools, these social injustice and inequalities are supported, thereby perpetuating the status quo. How do schools promote oppressive and unjust power relationships? Perhaps, they do this by placing the teacher at the front of the classroom who is viewed as possessing and transmitting the knowledge to students who sit idly "learning" or receiving the information (Giroux, 1987).

In Pedagogy of the Oppressed, Freire (1972) provides an illustration of how oppressive and unjust power relationships are maintained in what he calls the "banking concept of education" and further explains how critical literacy or liberative praxis can be well developed in an educational context. On the whole, it is tempting to connect Freire's thinking with Marxist view about the purpose of education. This is because, like Social Marxism, Freire thinks that meaningful education (critical literacy) ought to help break down the chains of oppression. These chains could be broken by what proponents of Education for Sustainable development (ESD) would call 'action competency' which in Freire's term is like praxis (Jensen \& Schnack, 1997). This study was constructed on this view about the purpose and meaning of education (critical literacy). In other words, this theoretical perspective was employed to guide us "define what should be studied, what questions should be asked, and what rules should be followed in interpreting the answers obtained" (Ritzer 1975 in Galliers 1992:64). In the following discussion, this paper briefly discusses the concepts that are commonly used in this paper.

\subsection{Banking Education}

Freire uses 'banking education' to describe pedagogical approaches that are oppressive and dangerous to students. Banking education is characterized by instruction that "turns [students] into 'containers,' into 'receptacles' to be 'filled' by the teacher." In such classrooms with John Locke's tabula rasa thinking, "knowledge is a gift bestowed by those who consider themselves knowledgeable upon those whom they consider to know nothing," (Coffey, 2010) and the teachers separate themselves as being the possessors of knowledge. In this role, the teacher neither necessarily challenges the students to think realistically nor values students' own "funds of knowledge" because he or she perceives his or her work as information transmission while his students believe the purpose of their education is for mere information acquisition (Hirsch, 1987).

Another feature of banking education is a milieu of fear and distrust, and students develop the dependency syndrome on educators. In fact, educators become the talking books, which are a true reflection of the bookish education (Bishop, 1985). In these learning environments, teachers often seek authority through Argumentum ad Baculam where one seeks authority through force or threats in the form of exams, for example. The educators take themselves as 'absolute knowers $^{2}$, and learners as people that know little, if any. Freire (1987) states this approach is a monologue, which denies

\footnotetext{
${ }^{1}$ In Freire's view, critical literacy is synonymous with liberative education or education that frees an individual from oppression.

2 According to Magfolda (1999:43-4), absolute knowers believe that knowledge exists in its absolute form and is held by authorities like books and experts.
} 
partnership in the social act of communication (teaching and learning process) and the full humanity of learners.

Further, often due to over-specialisation, anti-dialogical educators get so fixated in their knowledge cocoons that, at best, they can be described as academic zombies or monomaniacs; always walking and defending their fields and positions as the best and the only. Such educators would loathe Plato's opinion that education should be 'Man writ large', which means that education should bear the human face/nature. If it reaches this extreme, the process of indoctrination or hypnotisation on the educator is complete and any source of challenge is contemptuously viewed as an enemy, not just an adversary. Consequently, like Ronald Dore (1976) contends in The Diploma Disease, students learn from the teacher to obtain certificates; not the capacity or mindset-change to do things better.

\subsection{Liberating Education}

In opposition to the banking model, Freire proposed a system in which students become more socially aware through critiquing of multiple forms of injustice. This awareness may not be achieved if students are not given the opportunity to explore and construct knowledge. Teachers (or lecturers ) who recognize the potential value of developing critical literacy do not view their students as containers to be filled, but instead create experiences that offer students opportunities to actively construct their own knowledge. In this model, schools (or universities) become spaces where students interrogate social conditions through dialogue about issues significant to their lives. In other words, teachers (or lecturers) engaged in critical literacy, serve less as instructors and more as facilitators of conversations that question traditional power relations (Coffey, 2010).

Along these schools of thought, recognising every learner as potentially intelligent and centric in the learning process is pivotal. Freire argues that since learners have different intelligences and experiences, the classroom becomes a microcosm for sharing every learner's world with others so that when they go out they can change the outer world using the new world created from this sharing.

The view of paying adequate attention to every learner is in keeping with the concept of multiple intelligence thinking, (Gardner, 1983 and; Richards \& Rodgers, 2001). This theory states that everyone is intelligent except that we are intelligent in different areas and that we exploit our intelligences differently. With this view, for instance, a university professor, may not necessarily claim (without faulting themselves) to be more intelligent than say, a welder or any other professional. This understanding does not only support Gardner's Multiple Intelligences theory but much so that learning is more about experiential exchange and reflection (Santrock, 2006). In the liberating education, therefore, education constitutes genuine dialogue between the teacher (who is also a learner) and the learner (who is also a teacher by providing a context for everyone to construct and interrogate theories of knowledge. Open-ended questions that touch on all domains are used as some of the tools of teaching/learning. As Aronowitz (1998) also assesses, this approach is used because the role of the educator 'is to encourage human agency, not mould it in the manner of Pygmalion ${ }^{3}$.

In this paper, the use of words like 'teacher' or 'educator' does not contradict with Freire's view that an educator (teacher or lecturer) is essentially a learner. Etymologically, the word 'educate' stems from the Latin word educere, which literally means 'to draw out' what is latently there. The role of the teacher, therefore, is to help develop (draw out) potentials and abilities that learners have. This pedagogy is related to Socrates' metaphor for an educator as 'midwife' helping (learners) to give birth to ideas (Cooney, 1993:31). But like Youngman, Freire believes that 'education must help people in the process of objectifying the world, critically understanding it, and acting to change it' (Youngman, 1986:171).

In tandem with Confucius' thinking, the educator, who is committed to developing critical literacy in learners at any level, presents one corner so that learners explore other three corners. Shor (1987), in an apology for Freire's pedagogy, contends that the dialogical methods for critical literacy empower 'teachers and students to question existing knowledge as part of the questioning habits appropriate for citizens in a democracy' (McLaren and Learnald, 1993:25). From this view, educators need to always ask themselves whether their teaching is helping the learners and themselves to critically look at the content from all possible angles or not.

\subsection{Features of Literacy}

The preceding sections attempted to offer understanding of Freirean's view of an ideal education system. The following discussion is centred around the varying perspectives or descriptions of literacy. According to the Freirean typology, literacy can be grouped into three categories namely functional literacy, cultural literacy and critical literacy (Mayo,

\footnotetext{
${ }^{3}$ Based on a Greek myth, Pygmalion was a man in a play entitled 'Metamorphosis', who wanted to make his prospective wife to think as logically as he wanted by avoiding fallacies, but when she attained that skill, she refused to marry him by recognising the same fallacies that Pygmalion taught her in Pygmalion's marriage proposal.
} 
2004:37). In a post-modern world of constant movement and influence of media technology on the students' motivation to learn, we can also add two more categories of literacy referred to as media and emotional literacies which are vital for this discussion on students' intellectual development.

\subsection{Functional Literacy}

Mayo (2004:37) defines functional literacy as 'the technical process of acquiring basic reading skills necessary for such actions as following instructions, reading signs, and filling in forms' (Mayo, p.37). As Lankshear observes:

To be functionally literate... comprises a minimal, essentially negative and passive state.... Of course, being able to read and write hardly bestows the power to create jobs where none exists, or to secure a liveable income where work is poorly paid. Functional literacy equips a person to respond to outside demands and standards, to understand and follow. (McLaren and Learnald, 1993:94)

This feature of literacy is basic and synonymous with the old colonial 3Rs: reading, writing and arithmetic. In fact, everyone needs this basic literacy in order to survive in a socio-economic system. The colonial governments and early missionaries overemphasised this kind of literacy in Africa because it was seen well enough for reading the Bible while at the same time making Africans tamed enough to be submissive to their white 'masters'. In other words, with this literacy, it is likely for one to function within defined and confined parameters. Since this is merely functional, most holders of this literacy, in stricto sensu, become so domesticated that, like most children, if you ask them to jump, they may not even ask how high, let alone why but will just obey the instruction so that are perceived to just 'function'.

Institutions that aim at achieving this literacy are characterised by judging whether one is literate or not through their mere ability to read or write. Therefore, functionally literate people could, be found even in higher institutions of learning like colleges and universities.

\subsection{Cultural Literacy}

It is argued that for one to be considered literate, they must acquire a great deal of information about their cultures (Hirsch, 1987). As McLaren explains, cultural literacy is a means by which one gains access to linguistic and cultural values necessary for interaction in society. This type of literacy is usually exposed to the learners through courses like history, language, literature and social studies. Cultural literacy prepares an individual to fit into an already existent social system. In fact, therefore, 'culturally literate individuals...understand the historical milieu in which they are operating and are able and willing to transmit the knowledge to others' (Adeyemi, 2000:17).

Like functional literacy, cultural literacy has a big likelihood of hypnotising the learner so much that his/her identity is subsumed in the identity of society, a sort of oppression by society. As Busia (1969) observes, overemphasis on collective consciousness often leads to summumbonum, whereby an individual fails to define himself/herself or his/her vision and life except through his/her society (Busia: 1969).

At an extreme level of cultural literacy, learned people are likely to be very tribalistic, or regionalistic or even racistic. Therefore, politically, people who are merely culturally literate are likely to behave like the 'common man' in Shakespeare's Julius Caesar who supports leaders because they have been emotionally and monetary manipulated. In short, such people do not use personal reason but mob-reason. Both traditional and Neo-Marxist theorists in education would argue against such an education system because they contend it is designed to perpetuate injustices that favour the few ruling elite.

This paper agrees that it is by way of cultural interaction with more knowledgeable members of a community within specific social, cultural, and historical contexts in which all of the participants are striving to make sense of the messages they encounter, (either from text or from each other), that learners become acquainted with new information (input) and not only through direct stimulation as suggested by some behaviourist theories (Du Toit, 1999).

\subsection{Emotional Literacy}

According to Smit (2008), students do not only use cognitive, but also emotional abilities when learning which heavily influence their academic performances. The emotional literacy which encompasses feelings, emotions, attitudes, interests, value-judgments, self-concept, and motivation comes first then intellectual performance follows. Hugo (2001) summaries that emotional literacy consists of five elements: self-concept, motivation, self-regulation, empathy and adaptability in relationships. Therefore, in order to develop students' critical thinking skills which will enable them to be successful in their tertiary studies, the influence of the affective domain on critical thinking should not be disregarded (Smit, 2008).

It is encouraging to note that self-motivation also plays an important role in the process of becoming critically literate. Conceptual learning is strengthened by the intrinsic motivation to become literate. Interest in a subject can further contribute to enrich the amount, depth and wealth of conceptual learning from a text of own choice (Smit, 2008). 
Intrinsic motivation such as involvement, inquisitiveness, and social interaction helps students to really understand the text and to use this newly acquired knowledge in problem-solving (Hugo, 2001). Furthermore, through access to critical literacy, university students' confidence and self-respect are increased. They can thus integrate more easily and rationally into the academic culture of their tertiary academic institutions. (Smit, 2008).

\subsection{Media Literacy}

Summers (1997) describes media literacy as encompassing skills and knowledge needed to question, analyze, interpret, and evaluate the messages of the mass media conveyed outside the classroom walls in movies, television programs, music, radio talk shows, newspapers, magazines, posters, and the Internet. In essence, media literacy is the application of critical thinking to the messages of print and electronic media.

The paper has so far explained the four features of literacy presented in order of complexity. Attention is now drawn to the third and most powerful dimension of literacy - critical literacy which the leader in this field Paul (1985) describes as "learning how to ask and answer questions of analysis, synthesis and evaluation, [and] the ability to reach sound conclusions based on observations and information" (p. 37).

\subsection{Critical Literacy}

Critical literacy has been defined differently by numerous educators, theorists, and linguists. A range of definitions that appeared in the literature and those provided by students were reviewed and synthesized into four dimensions proposed by Cummins (1980). They are (1) disrupting the commonplace (descriptive phase), (2) interrogating multiple viewpoints (personal interpretative phase), (3) focusing on socio-political issues (critical analysis phase), and (4) taking action and promoting social justice (creative action). The definitions given by other scholars will be discussed first and those offered by students in the present study will be reviewed in the following section.

\subsubsection{Disrupting the Commonplace (Descriptive Phase)}

Freire argues that 'reading is re-writing what you are reading. Reading is to discover connections between the text and the context of the text, and also how to connect the text/context with my context, the context of the reader (Freire, 1987:10-11). Critical literacy is also said to be the ability to evaluate statements or arguments put forward by others (Pienaar, 2001).

\subsubsection{Interrogating Multiple Viewpoints (Personal Interpretative Phase)}

Critical literacy is probably what Magolda calls 'self-authorship' whereby a person is able to 'reflect upon one's beliefs, organise one's thoughts and feelings in the context of, but separate from the thoughts and feelings of others, and literally make up one's mind' (1999:6).

This phase enables a person to systematically and objectively analyse his/her knowledge, beliefs, and the beliefs of others. It is because critically literate people open their minds to their worlds and the worlds of others that Shor $(1987: 1)$ argues, with critical literacy, a person 'connects the political and the personal, the public and the private, the global and the local, the economic and the pedagogical, for re-thinking our lives and for promoting justice in place of inequality'. Another way of examining critical literacy is paying attention to and seeking out the voices of those who have been silenced or marginalized (Harste et al., 2000).

\subsubsection{Focusing on Socio-Political Issues (Critical Analysis Phase)}

Mayo summarises Freire's definition, by stating that it 'refers to the emancipatory process in which one not only reads the word but also the world,.... a process whereby one can perceive social, political and economic contradictions (which must force him/her to act) against oppressive elements of reality' (2004:37). The goal is to use literacy to engage in the politics of daily life and go beyond the personal and attempt to understand the socio-political systems to which we belong (Lankshear \& McLaren, 1993). Critical literacy is redefining literacy as a form of cultural citizenship and politics that increases opportunities for minority groups to participate in society and as an ongoing act of consciousness and resistance (Giroux, 1989). It is important to understand that texts are culturally, socially, politically, and historically constructed and situated (Lewison, 2002).

\subsubsection{Taking Action and Promoting Social Justice (Creative Action)}

Critical thinking abilities are powerful ways to promote social justice and the foundation of a just, humane, and democratic society (Smit, 2008). It is also a way of helping the individual student to better understand the society he/she lives in and to better negotiate for better conditions and services in that society. According to Reagan (2003), critical literacy education is like giving students the tools they need to make their own decisions - not only about learning, but also about every aspect of life.

In keeping with this perspective, Freire reiterates that critical literacy empowers a person to change the world. This 
political touch of critical literacy on changing the world for the better implies that a person should be critically literate both within and beyond society; or in Freire's words, should have one foot within society and another one strategically out. Having one foot outside society helps the person to grasp realistic visions. But keeping another foot within society helps to fully understand society and reduce risks of resistance to change by the society s/he wants to change. It is like the dilemmas and disjuncture about purpose learning and life that a philosopher in Plato's Allegory of the Cave is supposed to handle.

McLaughlin \& De Voogd (2004) describes critical literacy as focusing on issues of power relations that promote reflection, transformation, and action. It focuses on the problem and its complexity. The techniques that promote critical literacy are dynamic and adapt to the contexts in which they are used. Critical literacy is challenging and redefines cultural borders, encourages students to be border-crossers in order to understand others, and creates borderlands with diverse cultural resources (Giroux, 1989).

According to Smit (2008), critical literacy is creating an environment to promote a critical stance in life. Therefore, it is not surprising that students who engage in critical literacy are supposed to become open-minded, active, strategic readers who are capable of viewing text from critical perspectives. They would understand that the information presented in text, maps, newspapers, academic journals, and websites have been authored for a particular purpose. They would know that meaning is "grounded in the social, political, cultural and historic context of the reading event" (McLaughlin \& De Voogd, 2004:56). With the foregoing understanding, this study found it a niche to classify students' views and understanding of literacy education into Freire's main frames.

\section{Research Methods}

This study firstly delved into literature by and about Freire in order to analyse and classify the concept of 'literacy education'. Having framed that perspective, qualitative data was collected from 37 undergraduate students (year 2 and 3) from Bunda in Malawi and University of Zambia about how they understood the meaning of literacy and good literacy education. The guiding questions were: What do students think it means to be literate? What do students think is good literacy teaching? What do the students think is good literacy learning? What do students think are attributes of a bachelor's graduate who has developed good literacy skills (critical literacy)? What do students think is good learning or education in general? To which framed levels of Freire's meaning of literacy do the above students' responses fall?

Data was collected first from one-on-one interviews with the selected students then from focus group discussions (FGDs). Four FGDs were conducted: two from University of Zambia and two from Bunda with roughly 10 members each. During FGDs, male students were in their own groups just like female students too were. In both one-on-one interviews and FGDs, the interviewers could probe with questions so that they could assess what level of definition or meaning of literacy education the responses implied. The responses were recorded in a vignette rubric for interpretation. Choice of this qualitative approach was made by the understanding that "qualitative method investigates the why and how of decision making, not just what, where, or when". The data was analysed thematically in accordance with the categories of framed meaning of literacy. To deepen understanding, data collected through vignettes, were peer interpreted before a consensus understanding and interpretation was made about the responses.

\section{Results and Discussion}

\subsection{Summary}

This section presents and discusses findings of the study in the context of Freire's levels of literacy. In general, this study revealed that students from the two universities indicate to possess sufficient knowledge about literacy but at the lower levels. They are able to define, describe and comment on what they have learned about the meaning of literacy. But very few go beyond that. In this case, they can be said to understand well fundamental levels of literacy but not much of critical literacy skills. This scenario could, among other causes, be due to challenges brought about by FPE and massification in higher education which has negatively affected both the teaching and assessment of large classes.

\subsection{Findings and Interpretation}

In this study, students provided a number of specific ideas on their understanding of critical literacy and indicators of a good education in general. An evaluation of the responses by the students indicates that their understanding and interpretation of the subject in question is generally at basic and functional levels of literacy.

From the whole study, the following are some of the female students' definitions and interpretations of critical literacy:

"understanding extreme point of literacy, analysing things."

"intense kind of learning."

"to learn how to read and write."

"ability to read critically." 
"the ability of writing as well as speaking critically, making no mistakes"

"serious, educated, trying to learn in a deeper way, person who discovered light had critical literacy"

"being able to understand and explain words that are mostly not used in the lay man's language."

"ability to educate society."

"the ability to read and write for one to probably understand the situation of life around us."

"the good quality of reading and writing."

The male students reported that critical literacy is:

"understanding."

"ability to know the language very well"

"The kind whereby a person is enabled to understand things and utilise the knowledge that someone has."

"being able to use simplified literacy."

"those who are educated."

"a situation whereby somebody has knowledge about a topic."

"kind of teaching and learning taught or learnt by focussing on special needs either mental or learning impairments."

"Learning that has to be dealt with or well thought out and also it is also thoroughly thought out teaching methodologies."

"ability to read and write"

"ability to read text in an active and reflective manner so as to understand it better."

"ability to get the requirements of education 3 -Rs reading, writing and maths."

"Serious ability to read, write and do simple maths."

"proper ability to read and write in a very sensible manner."

"reference to how good we are in analysing things critical, e.g ability to fish out relevant information rather than

irrelevant data."

"ability to understand and read and write text."

"instructional approach that advocates for the adoption of critical perspectives towards text."

Taken together, it is clear that the students' understanding and definitions of critical literacy fall mainly within the descriptive phase of literacy. Even comparison by university showed minimum differences as the differences were by wording, not meaning or complexity. As it can be noted above, comparing responses between male and female students also showed almost no significant differences. This surmises that the students are not able to interrogate socio-political positions by going beyond the personal and focusing on societal power relationships. The dimension of taking action and promoting social justice was less evident from their perspectives of critical literacy. For instance, instead of students challenging the criterion used that resulted into unfair allocation of bursaries; they may just explain that students are provided with sponsorship upon admission to university. In context, while asked to connect the role of critical literacy to social justice in the university, one student said "the connection is that if one knows what to read and write, they will know what belongs to them on paper".

Most responses to this question were similar to the above. This suggests that the students are at functional level of literacy as they are not even questioning why that is what belongs to them on the paper. It is like reading the direction of the bus and boarding it, which is among the expectations of basic literacy (reading). Moreover, they may not help change the world of others if they are blind followers of the written word (Freire, Mayo, Pienner, Magolda, Shor, op. cit). The similarity in responses from University of Zambia and the one from Malawi were too many to notice the difference. This could be because these universities have the similar geographical, cultural and historical backgrounds. Historically, both universities were British colonies and their systems were highly borrowed from the British education system which emphasized basic rather than critical literacy. The other reason could be because both countries are facing the challenges of high numbers of enrolment under inadequate human and infrastructural development. In such a context, students do not have enough time to practice or have one-on-one contacts with their lecturers except learning how to pass examinations. As Kieran Egan (2006) and Bertrand Russell (1926) allude to, balancing different aims of education tend to be difficult because each aim like examinations, socialisation and self-actualisation could lead into divergent education practice. This is evidently the case in the two universities where lecturers have too many students to teach and assess them using assessment items that are largely encourage descriptive rather than critical skills.

But there were also few exceptional cases from the responses. When one participant was asked what she understood by the term literacy, this is what was answered: "what do you mean by literacy, sir; I think there are people who are said to be literate but they are just so dull? Maybe am wrong!" With this response, much as we may not agree with this perspective, we would think that critical students should have been wondering in the same way. For it is with this kind of mindset that would lead into what Paul Kegan calls 'self-authorship', or differently put here as 'critical literacy' 
(Kegan, 1994 \& Magolda,2001).

\section{Conclusion}

This paper has made a critical analysis of critical literacy using the Paulo Freire's typology. By way of analysis, the paper has attempted to show how this theoretical framework of thinking can be applied to frame university students' thinking about literacy and education in general. To make it more practical, the paper used qualitative study to compare how the 37 sampled students from both University of Zambia and Lilongwe University of Agriculture and Natural Resources (Malawi) understood the meaning and implications of critical literacy. The study findings from both universities have indicated that mostly, students' responses fall under the descriptive phase of literacy, which is viewed as fundamentally essential but less critical level of thinking and learning. Therefore, the results surmise that universities should do more to promote higher levels of literacy and learning which would make students more critical, analytical, and better change agents of their worlds and the worlds of others. It is therefore recommended that more studies of this nature should be done in similar contexts using different approaches to understand how universities could better promote analytical and critical thinking and learning among their students.

\section{References}

Adeyemi, M. (2000). Social Studies in African Education. Gaborone: Pyramid Publishing.

Aronowitz, S. A. (1991). Postmorden Education. Minneapolis: University of Minnesota Press.

Beck, A. (2005). A place for critical literacy. Journal of Adolescent and Adult Literacy, 393.

Behrman, E. (2006). Teaching about language, power, and text: A review of classroom practices that support critical literacy. Journal of Adolescent \& Adult Literacy, 490-498. http://dx.doi.org/10.1598/JAAL.49.6.4

Cervetti, G. P. (2001). A tale of differences: Comparing the traditions, perspectives, and educational goals of critical reading and critical literacy. Reading Online 4(9).

Coffey, H. (2010). Critical literacy. Journal of Adolescent and Adult Literacy, 87.

Comber, B. (1993). Classroom explorations in literacy. Australian Journal of Language and Literacy, 16(1), $73-84$.

Comber, B. (2012). Negotiating critical literacies. School Talk, 6(3), 1-3.

Conley, M. (2008). Content area literacy: Learners in context. Boston: Allyn \& Bacon.

Cooney, W. C. (1993). From Plato to Piaget: The greatest Education Theorist from Across the centuries and around the World. Lanham: University Press of America .

Cummins, J. (1980). The Cross-lingual Dimensions of Language Proficiency: Implications for Bilingual Education and the Optimal Age Issue. TESOL Quarterly, 197 - 205.

D., F. P. (1987). Literacy: Reading the Word and the World. London: Routledge and Kegan Paul.

Du, T. F. (1999). The Development of Academic Literacy in the Mainstream Classroom: A Functional Model for Teacher Education. Journal for Language Teaching, 154-175.

Freire, P. ( 1996). Pedagogy of the Oppressed. New York: Pedagogy of the Oppressed.

Freire, P. (1972). Pedagogy of the oppressed. New York: Herder \& Herder.

(1997): Pedagogy of the Heart. New York: Continuum

Freire, P \& Shore, (1987). Pedagogy for Liberation. New York: Bergin \& Garvey.

Freire, P. (1998). Teachers as cultural workers: Letters to those who dare teach. Bouder Co.: Westview

Giroux, H. (1987). Literacy and the pedagogy of empowerment. In P. F. (Eds.), Literacy: Reading the word and the world (pp. 1-29).

Giroux, H. (1989). Schooling for Democracy. London: Routledge.

Gumport et al. (1997): Trends in United States Higher Education from Massification to Post-Massification. Stanford University: NCPI

Heyting, F. et al. Eds. (2001): Methods in Philosophy of Education. London: Rutledge.

Harste J. C., \& B. A. (2000). Supporting critical conversations. In K. M. Pierce, Adventuring with books (pp. 506-554). Urbana, IL: National Council of Teachers of English.

Hawkins, R. (2010): Experiential learning, action research and outreach: A comparative and gap analysis. Makerere: RUFORUM 
Hirsch, E. D. (1987). Cultural Literacy: What Every American Needs to Know. Boston. Boston: Mifflin Houghton.

Hugo, A. J. (2001). Lees en studier op tersiere vlak: die aff ektiewe komponent van lees verdien ook aandag. Journal for Language Teaching, 138- 157.

Janks, H. (2000). Domination, access, diversity, and design: A synthesis for critical literacy education. Educational Review, 175-186. http://dx.doi.org/10.1080/713664035

Jensen, B., \& Schnack, K. The Action Competency Approach in Environmental education. Environmental Education Research, 3(2).

Kasanga, L. A. (2006 ). Learners' belief systems and writing instruction. Journal for Language Teaching, 139-162 .

Knobel, M. A. ( 2002). Critical cyberliteracies: What young people can teach us about reading and writing in the world. . National Council of Teachers of English Assembly for Research.

Lewison, M. L. (2002). Taking on critical literacy: the journey of newcomers and novices. Australian Journal of Language Arts, 79(5), 8-20.

Lobron, A. (2007). The interdependence of social awareness and literacy Instruction. The Reading Teacher, 528-537. http://dx.doi.org/10.1598/RT.60.6.3

Marsh, J. (2000). Teletubby tales: Popular culture in the early years language and literacy curriculum. Contemporary Issues in Early Childhood, 119-123. http://dx.doi.org/10.2304/ciec.2000.1.2.2

Mayo, P. (2004). Liberating Praxis: Paulo Freire'e legacy for Radical Education and Politics. London : Praeger Publishers.

McLaughlin, M. ( 2004 ). Critical Literacy as Comprehension: Expanding Reader Response. Journal for Adolescent and Adult Literacy, 52 - 62. http://dx.doi.org/10.1598/JAAL.48.1.5

Ozga, J., \& Lawn, M. (1981). Teachers, Professionalism and class: A study of organised teachers. Brighton: Falmer

Paul, R. W. (1985). Bloom's taxonomy and critical thinking instruction. Educational Leadership, 36-39.

Pienaar, G. C. (2001). Teaching critical thinking skills in the language classroom. Journal of Language Teaching, 125-137.

Reagan, J. (2003). Critical Constructivism and Language Teaching: New Wine in new bottles. Journal of Language Teaching, 120-130.

Santrock, J. (2006). Educational Psychology. Boston: McGraw-Hill Co.

Shor, I. (1987). Educating the educators: A Freirean approach to the crisis in teacher education. In I. S. (Ed.), Freire for the classroom: A sourcebook for liberatory teaching (pp. 7-32). Portsmouth, NH: Boynton/Cook.

Shor, Ira. What is critical literacy? Journal of Pedagogy, Pluralism and Practice, 4(1).

Smit, T. (2008). Academic Literacy: What is in a Name? NERA Journal, 1-16.

Stevens, L. (2007). Critical literacy: Context, research, and practice in the $K-12$ classroom. Thousand Oaks, CA : Sage.

Summers, S. (1997). Media Alert! 200 Activities to Create Media-Savvy Kids. San Jose, CA: Hi Willow.

Thelin, W. H. (2005). Understanding problems in Critical Classrooms. College Composition and Communication, 114141.

Youngman, F. (1986): Adult Education and Socialist Pedagogy. Kent: Croom Helm.

\section{$(\mathrm{Cc}) \mathrm{BY}$}

This work is licensed under a Creative Commons Attribution 3.0 License. 